\title{
The Evolution and Enlightenment of the Idea of Achieving Great Unification by Using Military Forces
}

\author{
Fang Hua ${ }^{*}$, Feng Zhengzheng ${ }^{2}$, Hao Wenhui ${ }^{3}$, Guo Jianguo ${ }^{4}$, Zuo Yuan ${ }^{5}$, Liu Hui ${ }^{6}$ \\ ${ }^{I}$ Department of Information and Communication Training \\ College of Information and Communication, National University of Defense Technology \\ Xi'an, China \\ ${ }^{2}$ National Defense University \\ Beijing, China \\ ${ }^{3}$ Department of Information and Communication Training \\ College of Information and Communication, National University of Defense Technology \\ Xi'an, China \\ ${ }^{4}$ Department of Information and Communication Training \\ College of Information and Communication, National University of Defense Technology \\ Xi'an, China \\ ${ }^{5}$ Department of Information and Communication Training \\ College of Information and Communication, National University of Defense Technology \\ Xi'an, China \\ ${ }^{6}$ Department of Information and Communication Training \\ College of Information and Communication, National University of Defense Technology \\ Xi'an, China \\ *Corresponding author: hwhada12@sina.com
}

\begin{abstract}
The idea of great unification is very profound. Historically, China has overcome many risks of divisions and built a unified multi-ethnic country, which is deeply rooted in the idea of great unification. The idea of achieving great unification by using military forces sprouted in the Xia, Shang and Zhou dynasties, come into shape in the spring and autumn period and the warring states period, and was finally formed in the Qin and Han dynasties. Since then, it has been constantly developed and improved in the practice of war. It is of great practical significance to systematize it so as to nourish and cultivate the unbreakable fighting spirit of the officers and soldiers, to pool the mighty strength of building a strong army in the new era, and to accomplish the great cause of national reunification.
\end{abstract}

Keywords- great unification; the idea of using military force; reunification of the motherland

\section{Introduction}

The idea of great unification is very profound. It is the basis of constructing the view of the world in China. It is deeply embedded in the practice of war and has fostered the thought and institutional practice of using the army to safeguard national unity. The idea of achieving great unification by using military forces manifests itself in two dimensions: the war justification in the dimension of war mobilization and the fighting capacity stimulation in the dimension of war implementation. This idea has been clearly reflected in the military thoughts, military strategies and military systems in China's history, and is of great theoretical and practical significance to the construction and completion of the great cause of national reunification.
2."The Mandate of Heaven and the Punishment of Heaven": The Spout of the Idea of Achieving Great Unification by Using Military Forces

As early as in the chieftain period, the concept of "great unification" had become the source of Chinese civilization, which was not only influenced by the traditional agricultural economy of China, but also was out of the need to control the flood of the huge Yellow River and to prevent the invasion of northern nomadic tribes. During the Xia, Shang and Zhou dynasties, the idea of theocracy and the idea of patriarchal clan were often integrated into the idea of great unification, where with the help of "the mandate of heaven and the punishment of heaven", the legitimacy of the war was often justified, and the threat of the tribal separation was eliminated. 
The idea of great unification through military force was clearly and profoundly embodied in the dynastic replacement wars during Xia, Shang and Zhou dynasties. In the earliest military law of ancient China, "Gan Shi", there was a record that "it was heaven that who wants to destroy its life, and I was only punishing him according to heaven's command." Mencius said, "Since Ge Zai, Tang began to march and had won eleven battles. After that, no one could compare him." (It means that since the battle of Ge, Shang Tang won eleven battles and had no enemy anymore.) More importantly, "the people look for him like rain in times of drought", which expressed the simple vision of national unity and the thought of just war. Later on, sacrifice and war were considered as the greatest events of the country and the war was raised as the most important thing of the country. Under the strategic guidance of "matching heaven with virtue", the Western Zhou dynasty carried out the Mu Ye war with the help of "Punishment of Heaven" and thus united the whole country. The idea of achieving great unification by using military forces not only provided justification and legitimacy for the war, but also greatly stimulated the fighting spirit of the army in the war practice at that time.

During Xia, Shang and Zhou dynasties, there were countless conquering. Regardless of conquering "Nine Yi" in the east and "Nine Yuan" in the south in Xia dynasty, or fighting against "San Zong" in Shang dynasty, these conquering and fights reflect the ideological concept of great unification. They use "the mandate of heaven" to lead troops and maintain battlefield discipline. "No disorder is greater than no son of God" and "The son of heaven is responsible for rites, music and war" is a direct interpretation of the idea of unified military. "If the son of heaven is the commander of the army, royal princes are responsible to lead them; if Yuan Hou, the great power under the son of heaven, is the commander of the army, his officials are responsible to lead them." That is to say, the son of heaven has six armies, which are led by royal princes. The great power under the son of heaven has three armies, which are commanded by the emperor. The armies are built to fight against unjust countries. This also suggests the institutionalized construction of the thought of the unified use of force at that time. In the Western Zhou dynasty, the idea of "great unification" reached far beyond the field of war. It was established as a ruling ideology through theocracy, ritual making and patriarchal clan hierarchy. The word---“All earth belongs to the king, and all the people are subordinate to the king." ----is a reflection of it. However, due to the lack of a clear concept of territory at this time, rather than guarding the territory, "great unification" was still a kind of expansion of territory at that time, while the character of achieving great unification by using military forces had been very obvious.

\section{3."Building a Country by Ploughing and Fighting": The Occurrence of the Idea of Achieving Great Unification by Using Military Forces}

The concept of great unification was formally put forward in the "Gong Yang Biography" where it explained the "the first month of King Wen's calendar". Why did they use the first month of King Wen's calendar? That was because King Wen's calendar was the universal calendar. Originally, "great unification" only referred to the universal calendar at first. However, in the Spring and Autumn period and the Warring States period, the idea of achieving great unification by using military forces came into being.

Of the 3,791 recorded wars in traditional China, 657 took place in the pre-Qin period, of which 614 took place in the Spring and Autumn period and the Warring States period. Before the Zhou dynasty, the idea of achieving great unification by using military forces was mainly confined to kingship replacement and foreign army wars, where the feature of great unification had not yet been fully expanded. It gradually came into being during the wars among countries or governors in the Spring and Autumn period and the Warring States period. The original meaning of "great unification" is that "unification" is the most important. In the Spring and Autumn period and the Warring States period, the idea of achieving great unification by using military forces was embodied in the military strategy as advocating the justice of war and achieving the strategic goal of unified world with "orthodoxy" or "virtue" as the center. In the military operation, it was embodied as the way of "building a country by ploughing and fighting" to enrich the country and strengthen the army. At the level of war mobilization, it was used to unify the armed forces and stimulate the army's thoughts to achieve the maximum mobilization effect on the battlefield. For the purpose of war, it was emphasized to conquer cities and land and unify the country.

The idea of achieving great unification by using military forces was also clearly embodied in the thoughts of hundred schools and in all kinds of military books. Confucianism, Monism, Taoism, Legalism, Buddhism and the army all put forward their own thoughts on great unification. Confucius advocated that "the son of heaven is responsible for rites, music and war"; Mencius advocated "forming one country"; Xun $\mathrm{Zi}$ stressed "unifying the country"; Lao tzu's interpreted the idea as "Tao born one, one born two, two born three, three born everything" and so on. In particular, in the field of achieving great unification by using military forces, the legalist's thought of "ploughing and fighting" was obviously more suitable for China at that time and was widely used in the practice of war. Under the guidance of the thought of achieving great unification by using military forces, Qin unified the whole country through war. In this period, the idea of achieving great unification by using military forces gradually enlarged into the level of military leadership and military command, forming the fundamental institutional arrangement of military power, which greatly enriched its institutional system and connotation. Because 
the Confucian thought that "there was no righteous war in the Spring and Autumn period", the Confucianism that first explained the view of "great unification" was shelved or abandoned by various vassal states due to the lack of appropriate military thought in the Spring and Autumn period and the Warring States period.

\section{4. "Unifying the country": The Forming of Great Unification Military Thinking}

In Qin and Han dynasties, the idea of achieving great unification by using military forces was established and developed systematically. First of all, after the unification of Qin dynasty, the military power came to the emperor, which fundamentally changed the situation of the separation of military powers in Xia, Shang and Zhou dynasties as well as in the Spring and Autumn and the Warring States periods. Since then, the idea of achieving great unification by using military forces had at least three aspects: first, defend the invasion of northern nomadic peoples and maintain the world order; Second, put an end to violence and secession; Third, expand the territory during the replacement of the dynasties". After that, the idea of achieving great unification by using military forces was long established and developed in the later period of imperial China.

The idea of achieving great unification by using military forces was also gradually constructed in the practice of war. Chen tang, a general of the Western Han dynasty, was a deputy officer of the western region. When he was a general of the western Han dynasty, once Xiong $\mathrm{Nu}$ attacked the surrounding areas in Kang $\mathrm{Ju}$ (today's Kazakhstan) and killed the ambassadors of the Han dynasty, thus threatening the security of the Western frontier of Han Dynasty. At that time, Chen Tang advocated sending troops to attack, but the commander Gan Yanshou was hesitant. Chen Tang took advantage of Gan Yanshou's long illness, took the army to attack and won the battle against Xiong $\mathrm{Nu}$. Later, Chen Tang wrote a letter in the name of to the emperor explaining the idea of achieving great unification by using military forces, which said:

"I heard that the great justice of the world should exist in a unity of heaven and earth. In the past, there was the reign of the emperor Shao Kang and Yu Shun; now there is the reign of strong Han dynasty. Huhanye Chanyu, a branch of Xiong $\mathrm{Nu}$, has yielded to the reign of Han dynasty and become the barrier of Han dynasty in the north. Only Zhizhi Chanyu hasn't obeyed to the reign of strong Han dynasty. I, Gan Yanshou and Chen Tang, lead the just army to fight Zhizhi Chanyu...."

At this time, the idea of achieving great unification by using military forces had already contained a more profound meaning of national military governance. For example, the soldiers should be loyal to the emperor and the emperor held the supreme military command. Confucianism advocated by Dong Zhongshu interpreted great unification in the sense of country stability. After the transformation of Confucianism, the idea of achieving great unification by using military forces came to the top of national politics." Great unification was more understood as a view of the world. It gradually moved away from the national political center and became the cultural gene and thinking mode of politicians and militarists, which often played an important mobilization and organizational function in the war practice.

\section{5."Overcoming the Risk of Division": The Practical Inspiration of the Idea of Achieving Great Unification by Using Military Forces}

Why has China emerged as a "great unified" country while the west has embarked on the path of a "nation state"? Politicians, thinkers and theorists from all over the world have put forward their own views and analyses from different dimensions, providing many inspirations for a systematic and comprehensive understanding of the current world situation. However, any theory is a retrospective understanding and analysis of the world by later generations, including the vision of anthropologist about the world. The academic research on the thought of "great unification" mostly starts from the perspective of "great unification" as ideology, political philosophy and traditional culture, while research on the thought of "great unification" in the practice of war or the idea of using military force are rarely mentioned. At the same time, it also ignores the important practical significance of war in the construction of a country and the reunification of the motherland to some extent.

The method of using military force is also the control technique of war. As the ultimate goal of using military forces is achieving "great unification", the idea of achieving great unification by using military forces is not only an important military thought, but also an important military strategy, and is gradually formed in the systems and regulations in military practice. Historically, China has been able to overcome numerous risks of divisions to build a unified multi-ethnic country, which is deeply rooted in the idea of using military force to achieve great unification. In those days, when resisting the United States and aiding the North Korea, comrade MAO Zedong insisted on adding the slogan of "defending our country" as a strategic thought, which inspired a powerful fighting spirit by the idea of great unification.

In the new era, under the guidance of Xi Jinping's thought on strengthening the armed forces, the party, the state and the armed forces have reorganized their military thinking as to resolutely safeguard the core national interests, and to effectively solve the prominent problems of insufficient initiative in military force. China is the only major country in the world that has not yet completed the reunification of the motherland. To complete the reunification of the motherland is one of the three major historical tasks of our party. It bears on the fundamental interests and feelings of the Chinese people as well as the rejuvenation of the Chinese nation. On the premise of striving for peaceful reunification to the greatest extent possible, the party and 
the state have never promised to renounce the use of force. We must at all times resolutely use military means to deter and curb separatist activities for "Taiwan independence". An army is made for war. At present, we must strengthen the idea of achieving great unification by using military forces to ensure stability and to control the situation in peacetime and to win decisive victory in wartime. Therefore, the review and summary of the idea of achieving great unification by using military forces not only focuses on the supplementary construction of the relevant theoretical system, but also, more importantly, adheres to the realistic orientation and the problemorientation, and makes preparations at any time for the great cause of national reunification by explaining its practical significance, especially the practical enlightenment to accomplish the great cause of national reunification.

\section{Conclusion}

Following the historical root, the idea of achieving great unification by using military forces has gradually become clear and been internalized as the core of China's military culture. History has repeatedly shown that the reunification of the motherland is the common aspiration of all Chinese people; Only through reunification, national rejuvenation can be achieved. Today, the global political, economic and military pattern has undergone profound changes. The idea of achieving great unification by using military forces is the internal driving force for the overall modernization of China's armed forces, and it also determines that Chinese culture will eventually move to the center of the world.

\section{REFERENCES}

[1] Su Li. Constitutional System of Great Powers: institutional constitution of historical China[M]. Peking University Press, 2018: 13 .

[2] Jiang Ronghai. Nine lectures on the History of Chinese Political Thought[M]. Peking University press, 2012:56.

[3] Wang Shaoyan. Iron Blood and Rule of law: a biography of Shang Jun's law[M]. China University of Political Science and Law Press, 2016.

[4] Si Maqian. Records of the Grand Historian of China[M]. 2013: 303.

[5] Mao Zedong. Reflection on Feudal Theory-- selected from MAO Zedong Manuscripts Since the Founding of the People's Republic of China (vol. 13) [M]. Central Academic Press, 1998:361.

[6] Ban Gu.Book of Han [M]. China Publishing House, 1962.

[7] Li Xiantang. The Illusion of Great Unification: A Study of China's Traditional View of the World[M]. Social Sciences Academic Press, 2018.

[8] Political Work Department of the Central Military Commission: A Study Outline of Xi Jinping's Thought on Strengthening the Military[M]. PLA Press, 2019:7.

[9] Zuo Yian. Research on the Educational Mechanism of Youth Collectivism in the New Era[Z]. 2019 National Social Science Fund Project. Journal of National University of Defense Technology,2019. 